\title{
Adaptação para Pintura e Escrita
}

\section{Adaptation for Painting and Writing}

\author{
Johanna Noordhoek ${ }^{(1)}$, Aline Torquetti Ferreira ${ }^{(2)}$
}

Resgatar a autonomia e a independência do ser humano são objetivos da terapia ocupacional ${ }^{(1)}$. A divulgação de adaptações, utilizadas durante o trabalho clínico dos autores deste trabalho, visa a contribuir para troca de $\mathrm{co}^{-}$ nhecimento e experiência entre os profissionais, em prol do aprimoramento de recursos que melhorem a qualidade de vida de pessoas com artrite reumatóide.

Uma alteração freqüentemente encontrada nas mãos reumatóides é a deformidade em "pescoço de cisne" dos $\operatorname{dedos}^{(2)}$, que consiste de hiperextensão da articulação interfalangeana proximal e hiperflexão da interfalangeana distal (Foto 1), secundária ao envolvimento periarticular decorrente de intensa sinovite reumatóide, com destruição da articulação e dos elementos contensores do tendão ${ }^{(3)}$.

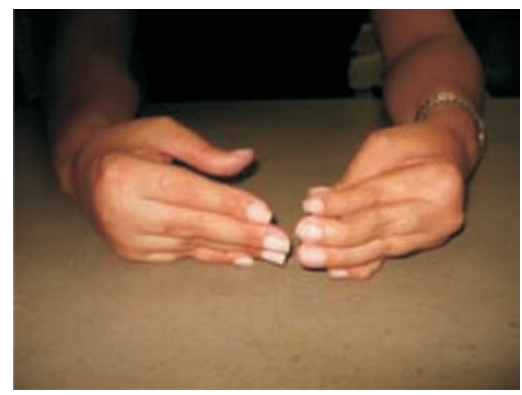

Foto 1 - Dedos em "pescoço de cisne".

A instalação da deformidade leva a distúrbio dos movimentos mais delicados das mãos ${ }^{(2)}$, que pode comprometer a execução de tarefas manuais. Atividades como a escrita e a pintura requerem força de preensão por tempo prolongado, além de movimentos repetitivos de punho e dedos (Foto 2). Sua execução pode ser facilitada com o uso de suporte confeccionado em metal leve, que permita o encaixe dos dedos e do material a ser utilizado (Foto 3 ).

Com a adaptação, o indivíduo desempenha as atividades fazendo uso de movimentos globais do membro superior,

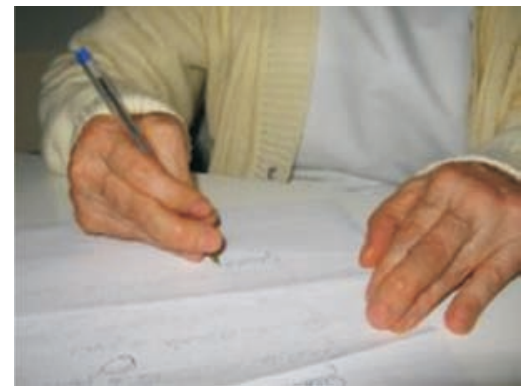

Foto 2 - Atividade de escrita sem uso da adaptação.

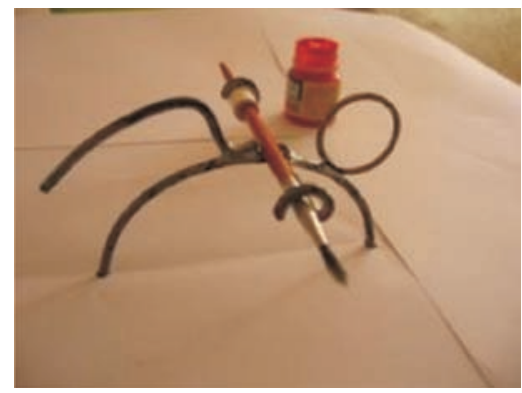

Foto 3 - Vista lateral da adaptação para a mão direita.

favorecendo a proteção das articulações acometidas pela sinovite, e a redução da dor e da fadiga (Fotos 4 e 5). A adaptação é feita com pequenos pedaços de metal, que podem ser reaproveitados, e unidos com o auxílio de um soldador. Para desenhar o molde, é preciso considerar os arcos palmares, o espaço suficiente para o apoio do polegar e dos demais dedos e o calibre dos materiais que serão utilizados, como lápis, canetas ou pincéis. Além do metal, pode-se pensar em fios resistentes ou materiais termomoldáveis para a confecção. O suporte é construído levando-se em consideração as necessidades e os interesses de cada pessoa. 


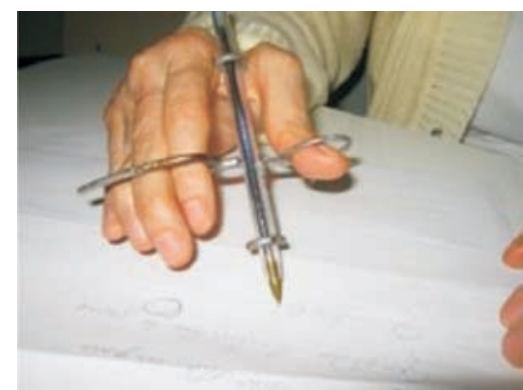

Foto 4 - Uso da adaptação para a escrita.

REFERÊNCIAS

1. Neistadt ME, Crepeau EB. Willard \& Spackman terapia ocupacional. Rio de Janeiro: Guanabara Koogan; 2002.

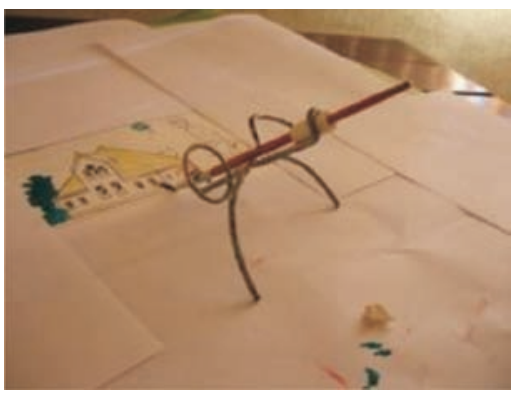

Foto 5 - Uso da adaptação para a pintura.

2. Freitas PP. Reabilitação da mão. São Paulo: Atheneu, 2005.

3. Azze RJ, Mattar Jr R, Canedo AC. Técnica cirúrgica para correção da deformidade em pescoço de cisne dos dedos. Rev Bras Ortop 28(4), Apr 1993. 